University of Wollongong

Research Online

University of Wollongong in Dubai - Papers

University of Wollongong in Dubai

$1-1-2012$

\title{
Enhancing the supply chain management performance using information technology: some evidence from UAE companies
}

\author{
Balan Sundarakani \\ University of Wollongong in Dubai, balan@uow.edu.au \\ Albert Wee Kwan Tan \\ University of Wollongong, altan@uow.edu.au \\ David Van Over \\ University of Wollongong in Dubai, davidv@uow.edu.au
}

Follow this and additional works at: https://ro.uow.edu.au/dubaipapers

\section{Recommended Citation}

Sundarakani, Balan; Tan, Albert Wee Kwan; and Van Over, David: Enhancing the supply chain management performance using information technology: some evidence from UAE companies 2012, 306-324.

https://ro.uow.edu.au/dubaipapers/140

Research Online is the open access institutional repository for the University of Wollongong. For further information contact the UOW Library: research-pubs@uow.edu.au 


\title{
Enhancing the Supply Chain Management performance using Information Technology: some evidence from UAE companies
}

\author{
Balan Sundarakani \\ Faculty of Business and Management, \\ University of Wollongong in Dubai, \\ Block 15, Knowledge Village, \\ P.O. Box 20183, Dubai, UAE \\ E-mail: balansundarakani@uowdubai.ac.ae
}

\author{
Albert Wee Kwan Tan* \\ The Logistics Institute - Asia Pacific \\ National University of Singapore, \\ 21, Heng Mui Keng Terrace, \#04-01, \\ Singapore 119613 \\ E-mail: isstana@singnet.com.sg \\ ${ }^{*}$ Corresponding author
}

\section{David Van Over}

School of Business Administration, American University in Dubai, P.O. Box 28282, Dubai, UAE

E-mail: dvanover@aud.edu

\begin{abstract}
The objective of this paper is to investigate Supply Chain Management (SCM) performance of selected companies in the United Arab Emirates (UAE) countries upon successful implementation of Information Technology (IT) applications. By carrying out an in-depth qualitative analysis, the paper seeks to evaluate how IT can enhance the SCM performance from a practitioner perspective. The survey results have indicated that respondents are aware that adopting IT does not necessarily translate to immediate benefits. Companies in UAE will, therefore, need to 'educate' their senior managers on using IT systems to streamline their supply chain operations, reduce cycle time and improve supply chain visibility. While most respondents have implemented IT systems for transactional processing, more can be done to implement more advanced IT systems for better planning and decision-making.
\end{abstract}

Keywords: IT; information technology; SCM; supply chain management; performance measurement; survey; middle east countries.

Reference to this paper should be made as follows: Sundarakani, B., Tan, A.W.K. and Van Over, D. (xxxx) 'Enhancing the Supply Chain Management performance using Information Technology: some evidence from UAE companies', Int. J. Logistics Systems and Management, Vol. x, No. x, pp.xxx-xxx. 
Biogr $\equiv$ al notes: Balan Sundarakani is the Assistant Professor at the Faculty Business and Management with the University of Wollongong in Dubai. Before this career, he worked as a Manager - Research and Senior Research Fellow at The Logistics Institute Asia Pacific, National University of Singapore, and Lecturer at National Institute of Technology, Trichy, India. $\mathrm{He}$ earned his BEng (Distinction) in Mechanical Engineering from MS University (now Anna University), Tirunelveli, and MEng (Distinction) in Industrial Engineering from National Institute of Technology, Trichy, and $\mathrm{PhD}$ in Supply Chain Management from Indian Institute of Technology, Roorkee, India. He has seven years of teaching and research experience in the area of operations management, supply chain management and green logistics, enterprise resource planning, electronic trading and transportation, robust optimisation and modelling and simulation. He has published more than 50 research papers in referred international journals such as Omega, IJPE, $J A M R$ and IJTM and conference proceedings. He has completed research and consulting projects for EDB, IBM, DHL and Mindef organisations.

Albert Wee Kwan Tan's research interests are in reverse logistics, process modelling, reengineering and information technology to coordinate supply chain. He holds an MBS from the National University of Ireland and a PhD in Supply Chain Management from the Nanyang Technological University. His research works have been published in International Journal of Physical Distribution and Logistics Management, International Journal of Logistics Systems and Management, International Journal of Logistics Management and the Asia Pacific Journal of Marketing and Logistics. He has worked as a Director for Singapore government, responsible for upgrading the IT capability of the manufacturing and logistics industries. This involved planning and evaluating e-commerce solutions for a variety of industries. He has also provided numerous BPR consulting for both public and private companies in Asia to streamline their operations.

David Van Over is the Dean of the School of Business Administration in American University of Dubai and teaches courses in Information Technology. $\mathrm{He}$ received a $\mathrm{PhD}$ in Information Systems, an MBA in Market Research, an MA in Psychology and a BA in Psychology all from the University of Houston (USA). Prior to joining UOWD, he held similar positions in American universities, including University of Georgia, University of Idaho, University of Houston and Texas A\&M University. He is a corporate consultant, trainer and group facilitator. He was employed by both Deloitte \& Touche and IBM as a business consultant. He also has extensive industry experience in the oil and gas and engineering fields. He has worked as a systems analyst and system designer (six systems) and was the Director of IT for an international oil and gas services company.

\section{Introduction}

A global supply chain is a network of factories and material sourcing on a worldwide basis. Global supply chains are a mechanism by which firms can achieve a competitive advantage of either low cost or differentiation through the processing activities performed and their corresponding linkages with suppliers and buyers (Klassen and Why bark, 1994). These networks have to be carefully managed to improve quality and reduce cost as well as lead-time. This requires controlling the inbound, outbound and 
procurement functions (Porter, 1986; Ellram and Carr, 1994) with a supporting IT-based system (Goonatilake, 1990). In today's global marketplace, organisations are faced with ever-changing customer requirements and intensified competition. To succeed in these challenges, companies are looking at re-engineering their supply chain through the successful deployment of IT.

A golden opportunity for the present globally integrated supply chain is the development of recent IT and communication, which leads to the integration of technology and system architecture (Balan et al., 2006). Moreover, optimal IT-based information sharing reduces the need for information sharing in the organisation (Balan et al., 2009; Larson and Kulchitsky, 2008). Mason-Jones and Towill (1999) used IT as a decoupling point to improve the performance of supply chain and considered information as a commodity. Although demand information acting as a decoupling point was originally introduced in the supply chain context by Christopher (1998), $\mathrm{Sjo} \equiv$ and Romme (1992), this was applied in supply chain performance measurement by Mason-Jones and Towill.

IT provides many essential applications in improving performance in supply chain. Advances in IT have made it possible for companies to develop and maintain a flexible organisation that can respond quickly to changing demands and conditions (Lee et al., $20 \equiv$ Besides improving supply chain efficiency, IT, which include the application of hardware, software and networks, could enhance information flow and facilitate decision-making in supply chain and logistics operations. While these lessons are invaluable to managers, there has been little research on how IT systems can effectively be deployed to improve the productivity in SCM.

\section{Literature review}

Logistics is becoming an important aspect of SCM (Carter and Ellram, 1998) and improving logistics velocity in turn increases the supply chain efficiency, and so the performance. Many companies that previously did not devote much time or energy to the management and understanding of logistics have begun to pay attention (Giuntini and Andel, 1995). Firms have begun to benchmark return operations against best-in-class operators (Stock, 1998). Third parties specialising in returns have seen the demand for their services greatly increasing (Stock, 1998). General literature in SCM and logistics measure is quite extensive (Tan, 2001) and a number of papers deal with supply chains. However, much of the literature is either too general or too specific to a particular country (Sum and Yang, 1993; Simatupang and Sridharan, 2002; Kemppainen and Vepsaelaeinen, 2003; Msimangira, 2003; Sahay et al., 2003). In addition, some of the performance measure literatures such as Caplice and Sheffi (1994), Beamon (1998), Brewer and Speh (2000), Lambert and Pohlen (2001) found highly cited and expressed the importance of enhanced supply chain performance.

Research shows that there are several SCM processes when it comes to the requirement of IT (Cooper et al., 1997) each of which has a completely different set of IT systems requirements to measure the supply chain performance. Although there have been no studies that explicitly look at the distinct IT system's needs of different supply chain processes, there is a clear body of work that examines various components of these processes and their effect on logistics performance. Research of IT and Information Systems in SCM has its roots in Electronic Data Interchange (EDI). Some researchers 
have omitted consideration of a large body of research including the impact of EDI on operations, for example, in warehousing (Rogers et al., 1992); Just-In-Time logistics (Srinivasan et al., 1994); replenishment and supplier reliability (Mukhopadhyay et al., 1995; Walton and Maruchek, 1997) and inventory management (Kekre and Mukhopadhyay, 1992; Lee et al., 1999). Logistics research recommended by Mentzer and Kahn (1995) provides substantial justification or the value of the research in the area of IT-driven logistics performance. It necessitates for the study to provide the rationale for undertaking this kind of study in the Middle East and North African (MENA) region.

More importantly regarding the impact of IT implementation and adoption, these studies have consistently shown a positive relationship between EDI and the following factors: improved product availability and customer service (Rogers et al., 1992); substantial reductions in shipment discrepancy (Srinivasan et al., 1994); lower documentation and administrative costs (Srinivasan et al., 1994; Reekers and Smithson, $19 \equiv$ and increased inventory turns and lower stock-outs (Lee et al., 1999; Mukhopadhyay et al., 1995). Finally, these studies span the globe covering North America, Europe and Asia. Understandably, the Middle East and Gulf countries are not covered. A recent survey presented by Svensson and Tronvoll (2008) predicted that $93-95 \%$ of the contributions in the selected top-quality logistics journal publications on survey-based research on SCM have come from geocentric locations of Asia, Europe, Australia and the USA. There is almost no such research paper being reported from Middle East countries and from the African continent.

Furthermore, the literature is limited in dealing with the degree of implementation of IT practices in SCM practices across countries and its performance in Middle East countries. A major study conducted by Arvis et al. (2007) measures the logistics performance index for 150 countries across the world. Figure 1 shows the results of some of the neighbourhood countries of UAE and their performance rankings. Singapore is rated as the best country in their study for all indicators, with UAE been placed in top 20 quartile with the Logistic Performance Index (LPI) score of 3.73 against best score of 4.19 (Singapore). It is interesting to find that all these Middle East countries are ranked within the top 50 out of 150 countries ranked, and it further stimulates us to investigate the study in detail in IT-related performance indicators among the companies operating in UAE.

Figure 1 Comparison of logistics practices of UAE with neighbouring countries (see online version for colours)

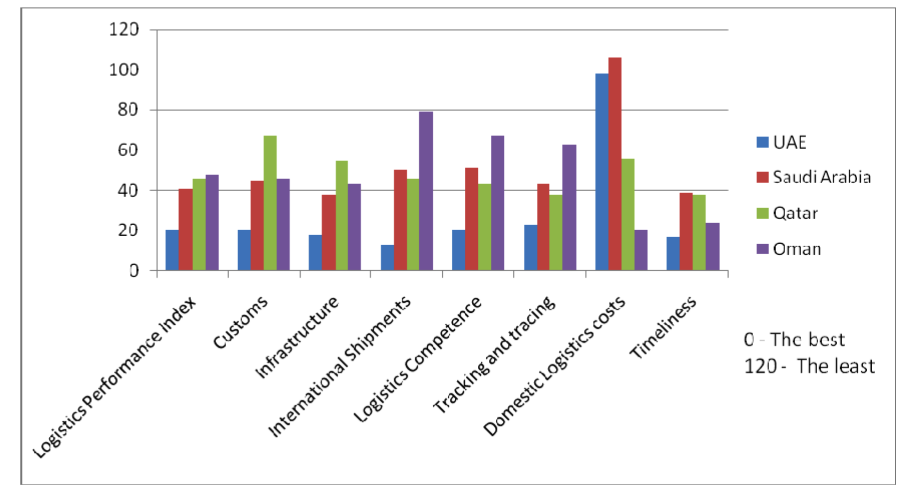

Source: Arvis et al. (2007) 


\section{Objectives of the research}

This research was aimed to reach out to a large number of manufacturing, trading and logistics companies to collect data about the usage of IT in their supply chain. The survey findings will give us insight into how IT is being used in today's changing supply chain landscape in the UAE. The objectives of the study are:

- $\quad$ to assess the IT adoption level; its applications, infrastructures and standards used for information sharing; and connectivity and its barriers to usage of IT

- to identify the potential IT skills needed by logistics professional to effectively manage logistics processes

- to identify future plans in using IT to enhance its competitiveness in the supply chain.

\section{Survey methodology}

The survey was conducted by using a survey questionnaire, which is divided into four main sections: organisational information, company strategies and directions, IT applications and the implementation of IT, and the adoption of emerging technology in the future. Understanding the organisational information helps us to understand the company profile, their supplier and customer profiles, and distribution of employees supporting logistics and IT. Similarly, knowing the company strategies and directions will help us to understand their company priorities in pursuit of SCM and whether these priorities are in line with best practices in the world.

Understanding the IT implementation for SCM allows us to gauge the current status of IT deployment in the industry in UAE. Expected IT deployment for the next two years is included to determine their future trends. Finally, our interests in knowing the company achievements through the implementation of IT and the adoption of emerging technology in the future will help us to understand the benefits of using IT in SCM and the types of IT skills needed to support logistics function. Using the survey framework, an online survey was conducted and e-mail invitations were sent to Supply Chain Logistics Group (SCLG) members on an unsolicited basis. The members were given three weeks to respond to the online survey.

The survey was designed using a framework illustrated in Figure 2. The key parameters in the survey framework consist of supply chain strategies, IT and achievements. The strategies adopted by companies to compete successfully in the market include JIT, Quick Response, Postponement and VMI. Technology serves as a solution for supporting the strategies to reduce operating cost and is closely linked with people and processes involved. Companies could benefit from their IT investments and achieve their objectives in investing in these technologies. 
Figure 2 SCM survey framework (see online version for colours)

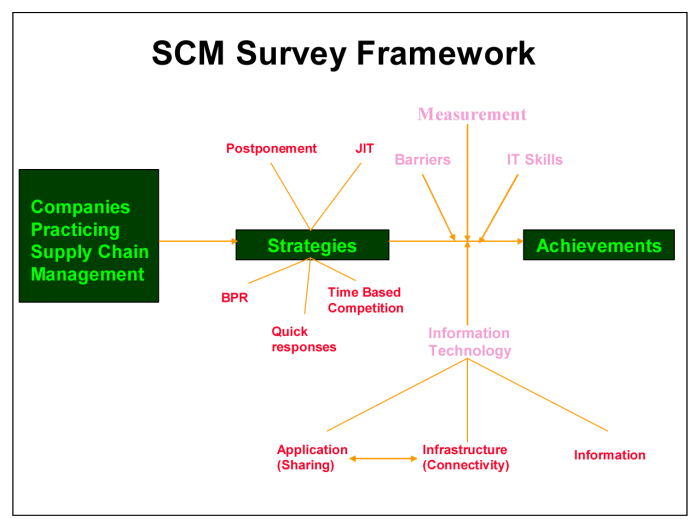

\section{Survey response}

An online survey was hosted in the university website and e-mail invitations were mailed to 300 companies from logistics industries, electronics, telecommunications, food and beverages, chemical and oil-related companies and other SCM-related organisations. The respondents were asked to respond using a five-point Likert scale for most of the questions. We received 47 valid responses from the SCLG members making a response rate of $22 \%$.

\section{Survey findings}

The responses are comparatively higher from Multi-national Companies (MNCs) that constituted almost half (45\%) of the total response, followed by local company $(30 \%)$ and Government linked company (15\%) (Figure 3). If we look at the profile of the survey respondents, around $40 \%$ of respondents were from local enterprises, of which $30 \%$ had more than $30 \%$ local equity. From the type of businesses, $31 \%$ of the respondents are logistics companies and $26 \%$ of them are trading companies (Figure 4). The rest of the respondents are a mixture of service companies. Classifying the survey respondents based on top 3 industry profile, among $22 \%$ of the respondents are from logistics industry, $13 \%$ of the respondents are from the Consumer Electronics industry and $9 \%$ of respondents are from the Telecommunication industry (Figure 5).

Figure 3 Ownership of company (see online version for colours)

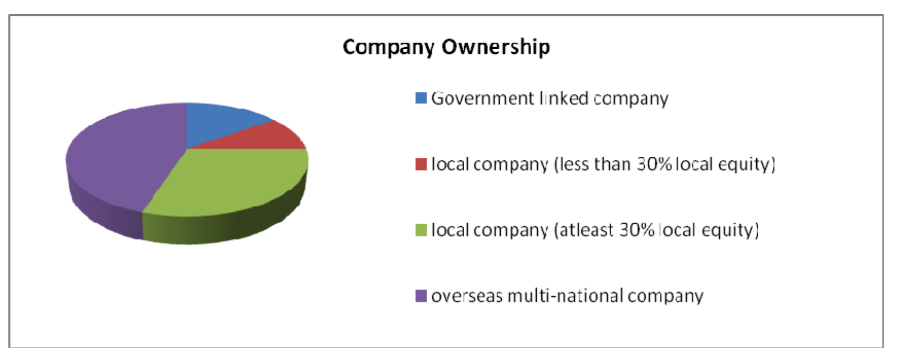


Figure 4 Type of business (see online version for colours)

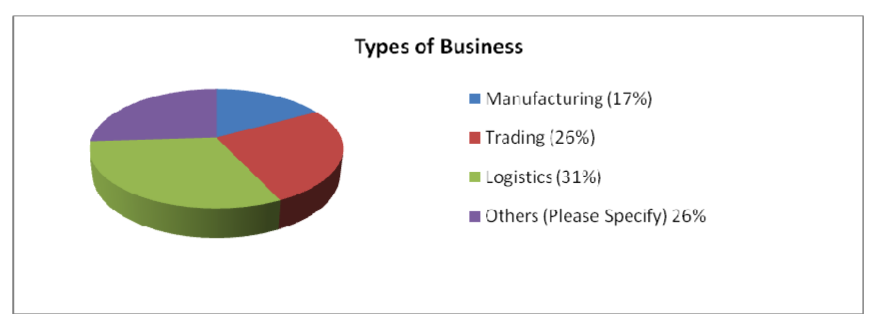

Figure 5 Type of industry (see online version for colours)

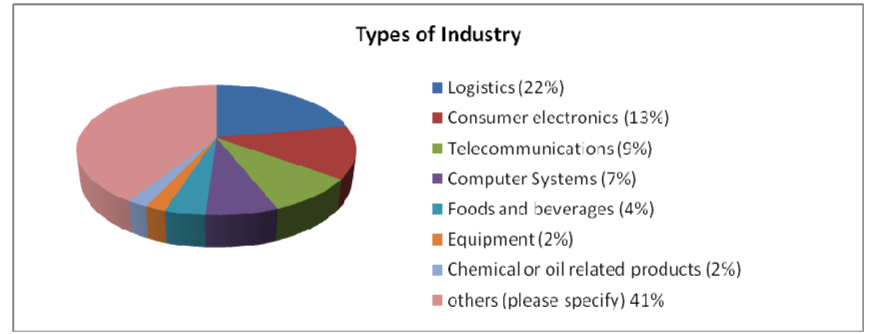

\subsection{Respondents profile}

On the basis of the respondents surveyed, about $49 \%$ of the respondents provide more than 500 products or services, while $33 \%$ provide less than 50 products or services. In terms of company size, close to $39 \%$ of the respondents have less than 100 employees and $39 \%$ have between 100 and 1000 employees (Figure 6). This means that majority of respondents are from small and medium size companies.

Figure 6 Number of products and employee responded (see online version for colours)
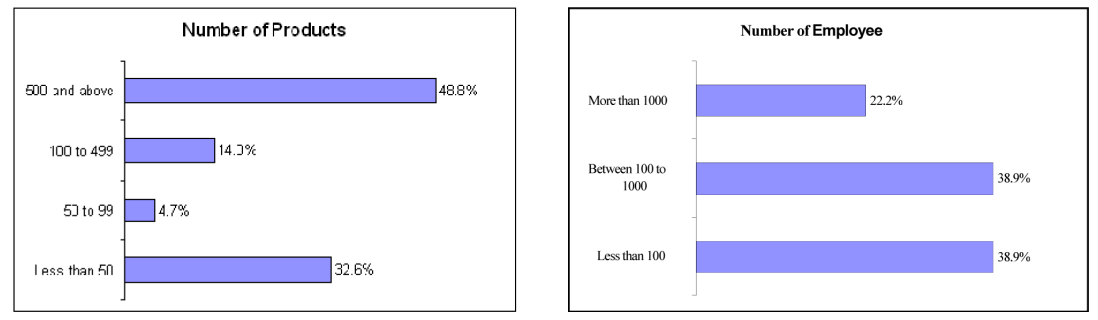

Almost 59\% of respondents employed less than 10 IT staffs to support their IT function. In contrast, more staffs are employed by the companies to support the logistics function (Table 1).

Table 1 Percentage of staff supporting IT and logistics functions

\begin{tabular}{lcc}
\hline Number of employees & \% Staffs supporting IT & $\%$ Staffs supporting logistics \\
\hline Less than 10 & $58.8 \%$ & $37.50 \%$ \\
Between 10 and 100 & $35.3 \%$ & $37.50 \%$ \\
100 or more & $5.9 \%$ & $25 \%$ \\
\hline
\end{tabular}




\subsection{Sourcing profile}

Figure 7 indicates that $39 \%$ of respondents have between 20 and 99 suppliers while $32.1 \%$ indicated that they have more than 100 suppliers. Only $7 \%$ of respondents indicated that they have less than 5 suppliers. Figure 8 shows that $39 \%$ of respondents indicated that they had an average of less than 50 components per active part number, while $43 \%$ of respondents had more than 1000 components per active part number.

Figure 7 Total number of suppliers (see online version for colours)

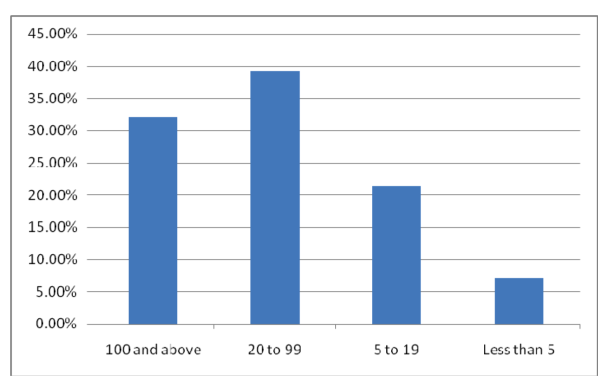

Figure 8 Number of different components per active part number suppliers per component (see online version for colours)

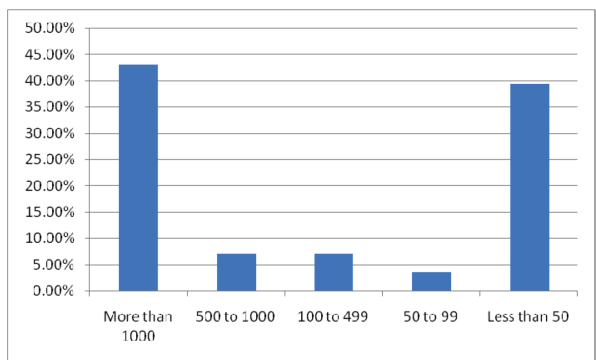

Further analysis shows that only $7 \%$ of respondents indicated that the average number of suppliers for each component is 1 when compared with $58 \%$ of respondents indicated that they have an average of 2-10 suppliers per component (Figure 9).

Figure 9 Average number of suppliers for each component (see online version for colours)

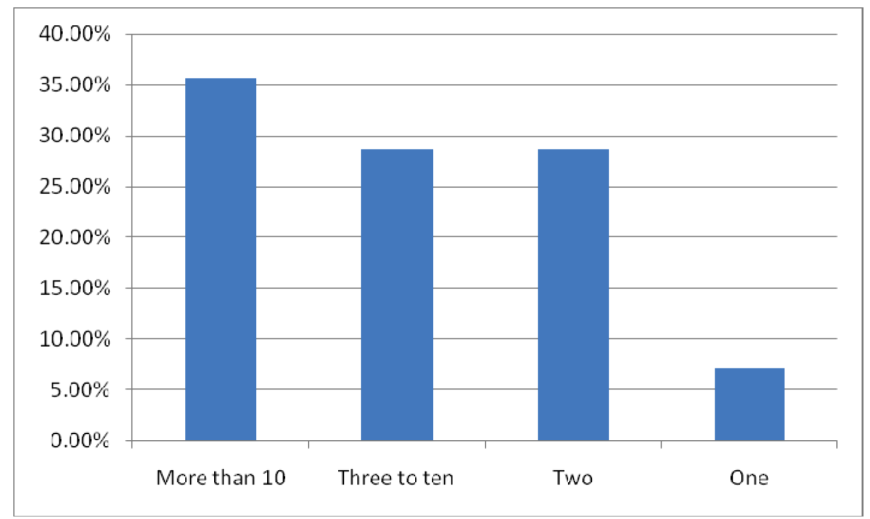




\subsection{Turnaround time between overseas and local supply chain}

More than 57\% respondents indicated that their local suppliers turn around within the same day or by the next day (Table 2). However, 39\% indicated that their overseas suppliers turn around within 2 weeks to 1 month. In term of customer delivery, $46 \%$ of respondents indicated that their turnaround time for local customer is between 3 days and 1 week. However, $61 \%$ respondents indicated that their turnaround time for overseas customers is between 3 days and 2 weeks. We can infer from the results that to fulfil the local and overseas customer order, companies need to keep inventory for about 2 weeks to 1 month if the materials are sourced from overseas suppliers. This is an interesting finding from this survey, as UAE is well known for its transshipment port, which is being considered as important enablers of European-Asian trade. With its air transport has been well developed, ship-air transshipment is very popular in UAE for international trading.

Table 2 Average turnaround time from suppliers and for customers

\begin{tabular}{lccccccc}
\hline & Same day & Next day & $\begin{array}{c}\text { 3 days to one } \\
\text { week }\end{array}$ & $\begin{array}{c}1-2 \\
\text { weeks }\end{array}$ & $\begin{array}{c}\text { 2 weeks to } \\
\text { 1 months }\end{array}$ & $\begin{array}{c}\text { 1-3 } \\
\text { months }\end{array}$ & $\begin{array}{c}\text { More than } \\
\text { 3 months }\end{array}$ \\
\hline $\begin{array}{l}\text { From local } \\
\text { suppliers }\end{array}$ & 14.3 & 42.9 & 23.8 & 9.5 & 4.8 & 4.8 & 0.0 \\
$\begin{array}{l}\text { From overseas } \\
\text { suppliers }\end{array}$ & 0.0 & 8.7 & 4.3 & 8.7 & 39.1 & 34.8 & 4.3 \\
$\begin{array}{l}\text { To local } \\
\text { customers }\end{array}$ & 13.6 & 31.8 & 45.5 & 4.5 & 0.0 & 4.5 & 0.0 \\
$\begin{array}{l}\text { To overseas } \\
\text { customers }\end{array}$ & 0.0 & 4.3 & 30.4 & 30.4 & 21.7 & 13.0 & 0.0 \\
\hline
\end{tabular}

\subsection{Profiles of supply chain members}

Survey results show that $67 \%$ of respondents indicated that their major market share is located overseas and $75 \%$ indicated that their major sources of materials are from overseas business suppliers. In terms of customer's profile, almost one-third of customers possesses their market share within the local territory (Figure 10).

Figure 10 Profile of customers and suppliers (see online version for colours)

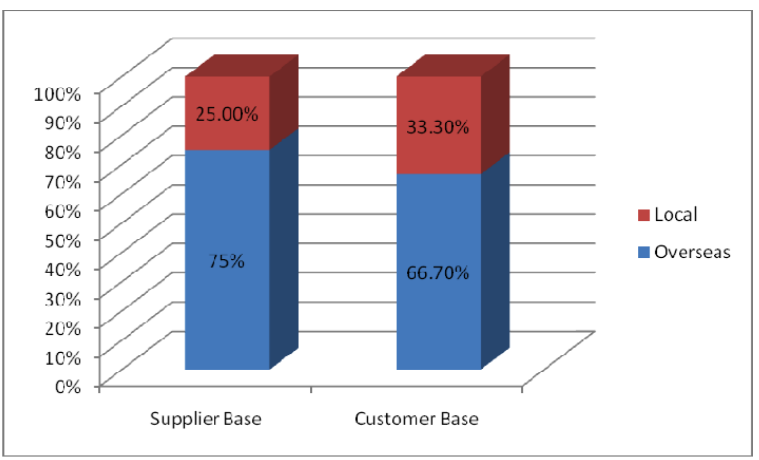


Most respondents indicated the most common method of transporting goods to and from UAE is by air (Figure 11). In the case of inbound logistics, sea transportation is the most common mode of transportation while in the case of outbound logistics, land transportation is the most common mode of transportation.

Figure 11 Mode of transportation for inbound and out logistics (see online version for colours)

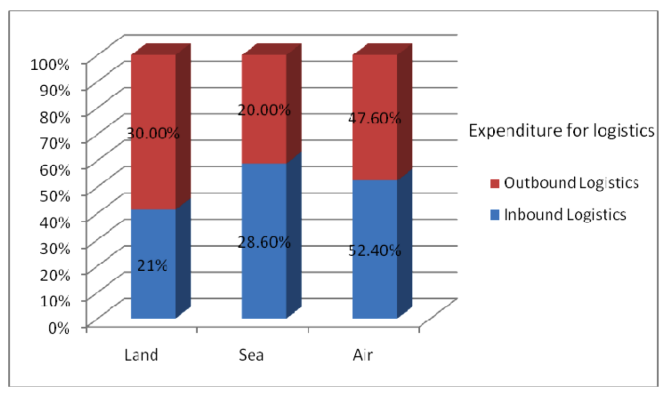

Nearly $76 \%$ respondents indicated that customer queries are answered within $4 \mathrm{~h}$ while $24 \%$ respondents indicated that they will take more than $4 \mathrm{~h}$ to answer customer queries (see Figure 12).

Figure 12 Average response time for customer enquiry (see online version for colours)

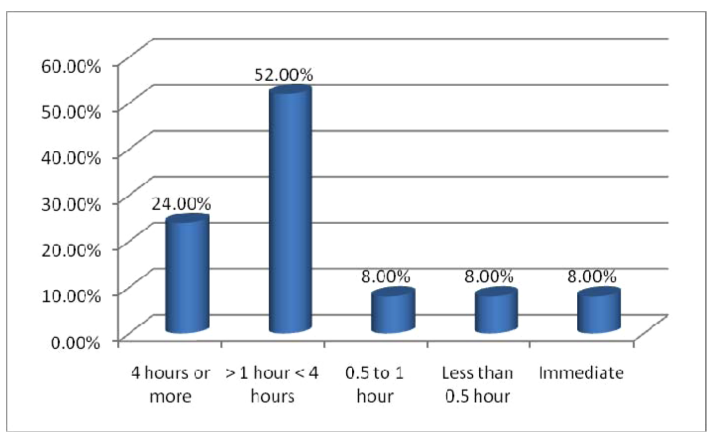

\subsection{Supply chain measurements}

Nearly $65 \%$ of respondents indicated that they have an annual logistics budget and the remaining 35\% indicated that they either have an ad-hoc budget or do not have a logistics budget. This is quite realistic as the logistics industry is a dynamic industry with fluctuating demands. On-time delivery was the most important and most recognised metric for logistics performance (Table 3). Accurate, complete and damage-free delivery, as well as inventory turnover, is also rated high amongst the performance metrics.

Table 3 Logistic performance metrics

\begin{tabular}{llc}
\hline Rank & Logistics performance & Mean and std. deviation \\
\hline 1 & On-time delivery & $39.26(+9.11)$ \\
2 & Inventory turnover & $35.66(+5.04)$ \\
3 & Accurate, complete and damage free delivery & $17.94(+3.23)$ \\
\hline
\end{tabular}


The top 3 logistics functions/activities outsourced are transportation/shipment, customs brokerage and warehousing or terminalling, while order processing was not demanded by respondents' customers. This trend is also reflected in the results from the past four years of the Third-Party Logistics (3PL) Study (Langley et al., $\equiv$ ), which reveal that warehousing and transportation, customs brokerage and waremousing remain the most popular services that 3PLs are currently outsourcing (Figure 13). These findings suggest that customers are slow to adopt services beyond the basics of transportation and warehousing.

Figure 13 Outsourced logistics activities based on type of service (see online version for colours)

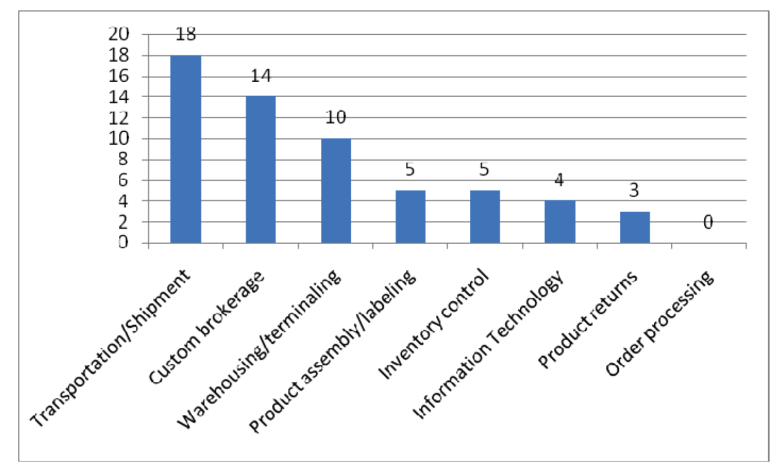

\subsection{Supply chain strategies and their achievements}

Logistics performance visibility, strategic use of IT and building logistics as its core strength are top three strategies adopted by the respondents (Table 4). However, most respondents do not agree that they have procedures in place for reverse logistics and proper partnership arrangement.

Table 4 Strategies adopted by organisations

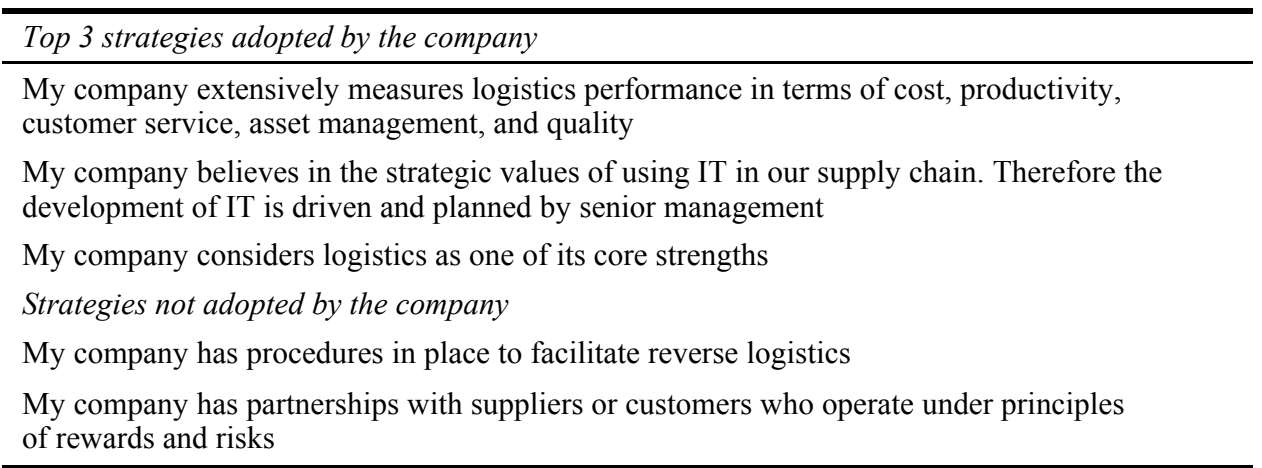

Implementing IT applications have helped companies to streamline their processes and have thus resulted in better productivity, quality and cycle time reduction. IT can capture data from the source, resulting in higher data quality. For example, Point of Sales (POS) technology may be used to obtain data that reflects real demand from customers. This allows the supply chain to respond realistically to the demand of the market

Author: Please check if the highlighted reference citation is ok 
and effectively reduce safety stock and average inventory. Respondents have indicated that IT has eliminated steps to reach customers and, thus, reduce the order cycle time.

Statistical and historical data collected can be used to identify customer behaviour in segmentation and to identify new markets (Table 5). However, respondents do not agree that IT has helped them to reducing the total systems inventory. We can infer from the survey results that to fulfil a local and overseas customer order, companies need to keep inventory for about 2 weeks to 1 month if the materials are sourced from overseas suppliers.

Table 5 Company achievements through implementing IT

\begin{tabular}{l}
\hline Top 3 achievements for using IT \\
\hline My company has eliminated intermediate steps/processes to reach our customers \\
My company has substantially reduced customer order cycle time \\
The quality of data has improved \\
Disagree with IT achievement \\
My company has consistently reduced total system inventory
\end{tabular}

\subsection{Barriers and motivation for using IT}

Justifying IT benefits, insufficient IT resources and long implementation time are key barriers for IT usage (Table 6). Long implementation time for IT systems with limited IT resources could result in long waiting time before the business can reap any tangible or intangible benefits from the initiative. In contrast, most respondents strongly agreed that the usage of IT is a necessity. Companies have to trade-off between benefit and cost. In fact, a lack of critical supply chain process visibility has been identified as the number one concern for global supply chain is in the Global Supply Chain Benchmark Report by Aberdeen Group (2006). Visibility tools will increase the responsiveness of the supply chain and thus reduces the inventory.

Table 6 Barriers to usage of IT

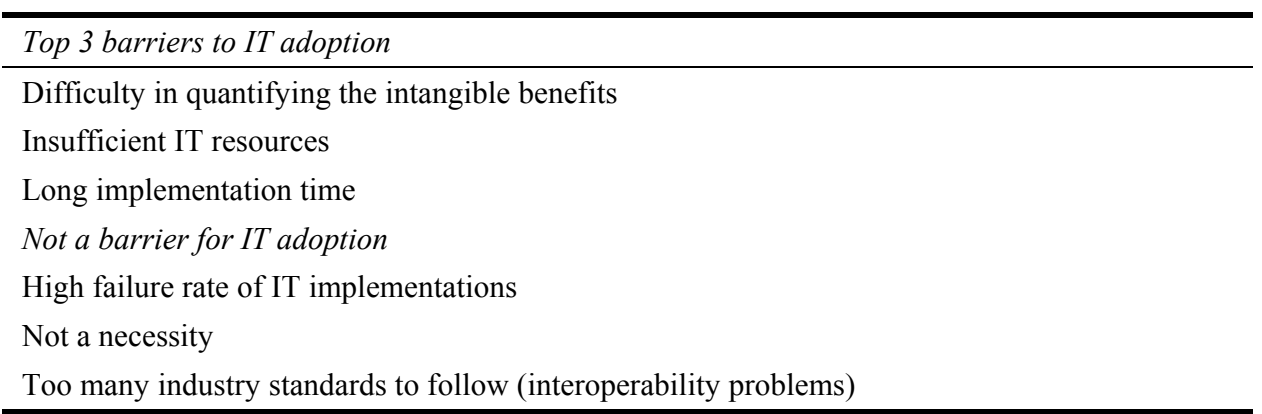

The primary motivations for adopting IT are driven by reduction of cost in terms of labour cost, inventory cost and order cycle time (Table 7). Most respondents also indicate that they are motivated to adopt IT as part of Business Process Re-engineering. 
Organisations embark on business process re-engineering with the same primary motivations to perform faster, reduce cost and improve their quality of service or products.

Table 7 Prime motivators for adopting IT

\begin{tabular}{lc}
\hline Top 3 motivations for IT adoption & Mean and Standard Deviation \\
\hline Reduce inventory & $46.01(+4.94)$ \\
Part of business process re-engineering & $25.96(+7.67)$ \\
Reduce order cycle time & $23.94(+2.23)$ \\
\hline
\end{tabular}

\subsection{IT implementation among the respondents}

As indicated by the survey respondents, most companies have implemented or are implementing transactional systems that include production control systems, sales order processing, inventory management systems and financial management systems (Table 8). These transactional systems are fundamental to manage the daily operational aspects of the individual functions of an organisation.

While transactional systems provide a basic picture of activities in each functional group of an organisation, they complement with the asset optimisation/planning systems that take the transaction data from each business function as the inputs, consolidate and optimise them to provide a complete integrated view of the whole supply chain. Therefore, Manufacturing Resource Planning (MRP), Master Production Scheduling (MPS) and forecasting systems are good examples of planning systems that use transactional data to plan for material and resources. Most respondents are aware of Supply Chain Planning applications (e.g., i2 rhythm) and have plans to implement these applications on their existing ERPs (Gruat La Forme et al., 2009). Others have indicated transportation system, network modelling and e-business systems for future plan.

Table 8 Implementation status of IT applications in supporting SCM

\begin{tabular}{|c|c|c|}
\hline $\begin{array}{l}\text { IT systems implemented } \\
\text { by company }\end{array}$ & $\begin{array}{l}\text { IT systems currently } \\
\text { implementing }\end{array}$ & $\begin{array}{l}\text { Plan to implement IT systems } \\
\text { in } 2 \text { years time }\end{array}$ \\
\hline Production control system & Forecasting & $\begin{array}{l}\text { Transportation management } \\
\text { system }\end{array}$ \\
\hline Sales order processing & Warehouse management system & Logistics network modelling \\
\hline Inventory management system & Purchasing management system & $\begin{array}{l}\text { Supply Chain Planning } \\
\text { system (SCP) }\end{array}$ \\
\hline Forecasting & $\begin{array}{l}\text { Manufacturing Resource } \\
\text { Planning (MRP II) }\end{array}$ & $\begin{array}{l}\text { Customer service/return } \\
\text { material management }\end{array}$ \\
\hline Financial management system & $\begin{array}{l}\text { Master Production Scheduling } \\
\text { system (MPS) }\end{array}$ & E-business systems \\
\hline
\end{tabular}

Groupware and automatic identification technologies are ranked highest amongst the technologies that respondents have adopted while relational databases, EDI and ERPs are ranked high as technologies currently implementing by respondents (Table 9). More 
advanced technologies (real-time system and automation system) are indicated by respondents for adoption in 2 years time (Maryam and Ghazi, 2011).

Table 9 Status of adopting technology in SCM

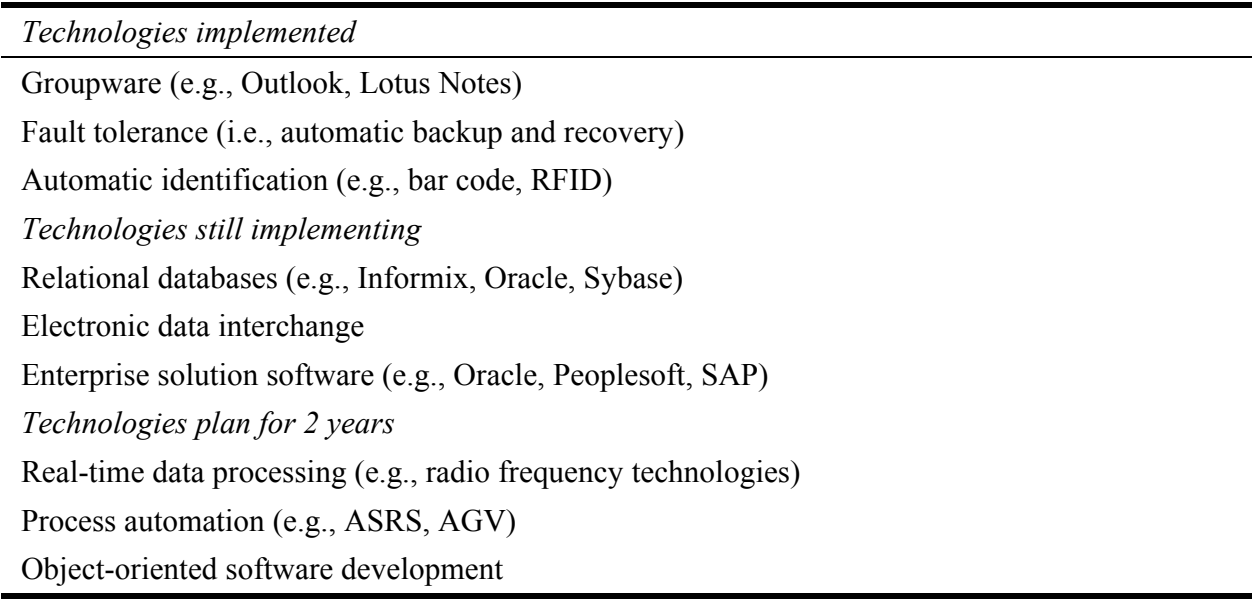

\subsection{Type of information for sharing among supply chain members}

As indicated by the survey respondents, accounting information is shared with suppliers, customers and within its company (Table 10). Order status is shared with suppliers and customers for order visibility while inventory status is shared with customer and intra-company for inventory visibility (Zygmunt, 2010).

Table 10 Type of information share by supply chain members

\begin{tabular}{lccc}
\hline & & Type of information for sharing \\
\hline $\begin{array}{l}\text { Information shared with } \\
\text { suppliers }\end{array}$ & Production schedule & Order status & $\begin{array}{l}\text { Account payables/account } \\
\text { receivables }\end{array}$ \\
$\begin{array}{l}\text { Information shared with } \\
\text { customers }\end{array}$ & Inventory status & Order status & $\begin{array}{l}\text { Account payables/account } \\
\text { receivables }\end{array}$ \\
$\begin{array}{l}\text { Information shared with } \\
\text { intra-company }\end{array}$ & Inventory status & Purchase/sales & $\begin{array}{l}\text { Account payables/account } \\
\text { receivables }\end{array}$ \\
\hline
\end{tabular}

\subsection{Critical skills for Supply Chain Management}

In general, effective management of the supply chain requires two distinct sets of skills, namely: logistics skills (the domain knowledge) and IT skills. Logistics skills facilitate the planning, execution and management of logistics processes in the whole supply chain. These skills can be acquired through education, training courses, seminars and conferences. IT skills relate to the ability to employ IT to effectively manage the activities in the whole supply chain, including computer networking, decision-support systems, database technology, logistics network modelling and simulation. From the feedback of the respondents, the top 3 IT skills identified as most important to support logistics operations are Spreadsheet, ERP software and the Operation System (Table 11). 
A spreadsheet is the traditional tool that has been used in planning and scheduling, while ERP is a transactional system commonly used to support order processing and planning.

Table 11 Important IT skills to support logistics function

\begin{tabular}{lc}
\hline Top 3 IT skills needed & Mean and standard deviation \\
\hline Spreadsheets (e.g., MS Excel) & $43.33(+9.44)$ \\
ERP software (e.g., SAP) & $35.66(+4.67)$ \\
Operating systems (e.g., Windows, Linux) & $27.94(+0.23)$ \\
\hline
\end{tabular}

\section{Managerial implications}

The survey has indicated that respondents are aware of the pros and cons in adopting IT but more efforts are needed to 'educate' their senior managers on the benefits of using IT systems to streamline their supply chain operations to reduce cycle time and improve supply chain visibility. The following trends can be inferred from the study:

- Transportation and warehousing are the most commonly outsourced logistics services, so it makes sense that transportation (TMS) and Warehouse Management Systems (WMS) are the most commonly offered applications for shippers. It is easier for 3PLs when shippers use the 3PL's applications, as it is either already integrated or easier to integrate with other 3PL IT systems. This also makes high switching cost for shippers seeking to switch 3PLs.

- Most respondents have implemented IT systems for transactional processing, but more can be done to implement more advanced IT systems for better planning and decision making. Measuring logistics performance and using IT strategically are high priorities for most of the respondents.

- Justifying IT benefits, insufficient IT resources and long implementation time are key barriers for IT usage to support logistics operations. These are issues related to poor project management skills. Because outsourcing involves simultaneous changes to organisation, business processes and IT platform, companies need to very carefully plan and execute outsourcing engagements both in the start-up phase and while managing ongoing operations. This finding suggests that companies need to recruit more personnel who are certified and experienced in planning and delivering projects.

- Companies want IT that can respond quickly to the needs of the business and that delivers value now without increasing IT costs later. They would like to leverage existing investments while allocating a higher percentage of resources to developing solutions that can support innovation vs. maintaining existing solutions.

- Implementing IT applications have helped companies to streamline their processes and thus resulted in better productivity, quality and cycle time reduction. This allows the supply chain to respond realistically to the actual demand from the market and 
effectively reduce safety stock or average inventory. Statistical and historical data can also be collected to identify customer behaviour in each segment and serve as inputs to forecasting systems that predict markets trends and seasonal demand.

- Respondents do not agree that IT has helped them in reducing the total systems inventory. We can infer from the survey results that to fulfil the local and overseas customer order, companies need to keep inventory for about 2 weeks to 1 month if the materials are sourced from overseas suppliers (Kritchanchai et al., 2010).

\section{Conclusion}

Customer expectations are increasingly demanding. More customers are expecting immediate responses from enquiries. These expectations can only be met if reliable and real-time information is readily available. IT and well-integrated business processes are the means of providing relevant and timely information. As more companies adopt IT as means of improving customer service, IT no longer becomes a competitive edge but a necessity. Respondents in the survey have clearly indicated that they believe that IT is a necessity.

Most respondents indicated that it is difficult to justify IT spending as well as getting IT resources. This suggests that although many companies are aware that IT is a necessity but they might not have a good approach in identifying company's needs and areas that can be improved by IT and prioritising them. They should manage IT projects to reap the benefits and determine if these can be managed in-house or outsourced IT operations effectively.

Furthermore, the survey also suggests that respondents are aware that adopting IT does not necessarily translate to benefits. Companies in UAE will, therefore, need to 'educate' their senior managers on the benefits of using IT systems to streamline their supply chain operations to reduce cycle time and improve supply chain visibility. While most respondents have implemented IT systems for transactional processing, more can be done to implement IT systems for planning and better decision making.

The authors assert that though the previous research had shown excellent qualitative study about this issue in other parts of the world, there exists a lot of scope to develop this study in Middle East countries. However, there are some limitations in this survey in terms of sample size and geography covered. Therefore, this study could be extended by increasing the sample size, geographical country and supply chain constructs considered to a larger scale. There exist wide opportunity to extend this study across countries for a larger sample size and can be compared with some of the leading logistics economies like Singapore, Netherlands and Hong Kong.

\section{Acknowledgement}

The study was supported by Supply Chain and Logistics Group (SCLG) in UAE. We sincerely acknowledge them for their contribution in making this research successful. 


\section{References}

Aberdeen Group (2006) Global Supply Chain Benchmark Report, UK, London.

Arvis, J-F., Mustra, M.A., Panzer, J., Ojala, L. and Naula, T. (2007) 'Connecting to compete: trade logistics index and its indicators', World Bank Report, pp.1-48. A VOLUME NUMBER.

Balan, S., Vrat, P. and Kumar, P. (2006) 'Assessing the challenges and opportunities of global supply chain management', International Journal of Value Chain Management, Vol. 1, No. 2, pp.105-116.

Balan, S., Vrat, P. and Kumar, P. (2009) 'Information distortion in a supply chain and its mitigation by using Soft Computing Approach', OMEGA: The International Journal of Management Science, Vol. 37, No. 2, pp.282-299.

Beamon, B. (1998) 'Supply chain design and analysis: models and methods', International Journal of Production Economics, Vol. 55, No. 3, pp.281-294.

Brewer, P.C. and Speh, T.W. (2000) 'Using the balanced scorecard to measure supply chain performance', Journal of Business Logistics, Vol. 21, No. 1, pp.75-93.

Caplice, C. and Sheffi, Y. (1994) 'A review and evaluation of logistics metrics', International Journal of Logistics Management, Vol. 5, No. 2, pp.11-28.

Carter, C.R. and Ellram, L.M. (1998) 'Reverse logistics: a review of the literature and framework for future investigation', Journal of Business Logistics, Vol. 19, No. 1, pp.85-102.

Christopher, M. (1998) Logistics and Supply Chain Management, 2nd ed., Pitman Publishing, Financial Times, London.

Cooper, M.C., Lambert, D.M. and Pagh, J.D. (1997) 'Supply chain management: more than a new name for logistics', International Journal of Logistics Management, Vol. 9, No. 2, pp.1-18.

Ellram, L.M. and Carr, A. (1994) 'Strategic purchasing: a history and review of the literature', International Journal of Purchasing and Materials Management $\equiv 10-18$. AUTHOR PLEASE SUPPLY VOLUME NUMBER.

Giuntini, R. and Andel, T. (1995) 'Reverse logistics role models: part 3', Transportation and Distribution, Vol. 36, No. 4, pp.97-98.

Goonatilake, L. (1990) 'Inventory management in the manufacturing sector in developing countries', Engineering Costs and Production Economics, Vol. 19, No. 1, pp.19-24.

Gruat La Forme, F-A. (2009) 'The role of APS systems in supply chain management: a theoretical and industrial analysis', International Journal of Logistics Systems and Management, Vol. 5, Nos. 3-4, pp.356-374.

Kekre, S. and Mukhopadhyay, T. (1992) 'Impact of electronic data interchange technology on quality improvement and inventory reduction programs: a field study', International Journal of Production Economics, Vol. 28, No. 3, pp.265-282.

Kemppainen, K. and Vepsaelaeinen, A.P.J. (2003) 'Trends in industrial supply chains and networks', International Journal of Physical Distribution \& Logistics Management, Vol. 33, No. 8, pp.701-719.

Klassen, R.D. and Why bark, D.C. (1994) 'Barriers to the management of international operations', Journal of Operations Management, Vol. 11, pp.385-396.

Kritchanchai, D., Tan, A. and Hosie, P. (2010) 'An empirical investigation of third party logistics providers in Thailand: barriers, motivation and usage of information technologies', IJISSCM, Vol. 3, No. 2, pp.68-83.

Lambert, D.M. and Pohlen, T.L. (2001) 'Supply chain metrics', International Journal of Logistics Management, Vol. 12, No. 1, pp.1-19.

Langley, C., Morton, J., Wereldsma, D., Swaminathan, S., Murphy, J., Deakins, T.A., Hoemmken, S. and Baier, J.M. (2008) Third-Party Logistics: The State of Logistics Outsourcing, 3PL Study Report. $\equiv$ HOR PLEASE SUPPLY FULL DETAILS. 
Larson, P.D. and Kulchitsky, J.D. (2008) 'The promise of information sharing and the peril of information overload', International Journal of Logistics Systems and Management, Vol. 4, No. 4, pp.423-443.

Lee, H.G., Clark, T. and Tam, K.Y. (1999) 'Research report: Can EDI benefit adopters?', Information Systems Research, Vol. 10, No. 2, pp.186-195.

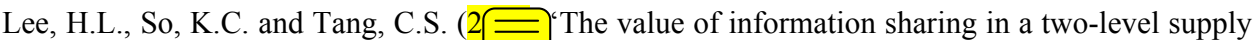
chain', Management Science, Vor 40 , pp.626-643. AUTHOR PLEASE CLARIFY IF THE YEAR OF PUBLICATION IS '2000' OR '2001'.

Maryam, S.N. and Ghazi, M.M. (2011) 'Application of wireless data systems on transportation logistics of the future', International Journal of Logistics Systems and Management, Vol. 8, No. 4, pp.444-470.

Mason-Jones, R. and Towill, D. (1999) 'Using the information decoupling point to improve supply chain performance', The International Journal of Logistics Management, Vol. 2, No. 10, pp.13-26.

Mentzer, J.T. and Kahn, K.B. (1995) 'A framework of logistics research', Journal of Business Logistics, Vol. 16, No. 1, pp.231-250.

Msimangira, K. (2003) 'Purchasing and supply chain management practices in Botswana', Supply Chain Management: An International Journal, Vol. 8, No. 1, pp.7-11.

Mukhopadhyay, T., Kekre, S. and Kalathur, S. (1995) 'Business value of Information Technology: a study of electronic data interchange', MIS Quarterly, Vol. 19, No. 2, pp.137-156.

Porter, M.E. (1986) Competition in Global Industries: A Conceptual Framework, Harvard Business School Press, Boston, MA, USA.

Reekers and Smithson, (1996) AUTHOR P $=$ SE SUPPLY FULL DETAILS.

Rogers, D.S., Daugherty, P.J. and Staß, T.P. (1992) 'Enhancing service responsiveness: the strategic potential of EDI', International Journal of Physical Distribution and Logistics, Vol. 22, No. 8, pp.15-20.

Sahay, B.S., Gavale, V. and Mohan, R. (2003) 'The Indian supply chain architecture', Supply Chain Management: An International Journal, Vol. 8, No. 2, pp.93-106.

Simatupang, T. and Sridharan, L. (2002) 'The collaborative supply chain', The International Journal of Logistics Management, Vol. 13, No. 1, pp.15-30.

Sjoerd and Romme (1992 $\equiv$ THOR PLEASE SUPPLY FULL DETAILS.

Srinivasan, K., Kekre, S. and Mukhopadhyay, T. (1994) 'Impact of electronic data interchange technology on JIT shipments', Management Science, Vol. 40, No. 10, pp.1291-1304.

Stock, J.R. (1998) Development and Implementation of Reverse Logistics Programs, Council of Logistics Management, Oak Brook, IL, p.270.

Sum, C.C. and Yang, K.K. (1993) 'A study of manufacturing resource-planning MRPII practices in Singapore', Omega: The International Journal of Management Science, Vol. 21, No. 2, pp.187-197.

Svensson, G. and Tronvoll, B. (2008) 'Empirical characteristics and geo-centricity in top journals of logistics management', The International Journal of Logistics Management, Vol. 19, No. 3, pp.436-450.

Tan, K.C. (2001) 'A framework of supply chain management literature', European Journal of Purchasing and Supply Management, Vol. 7, No. 1, pp.39-48.

Walton, S.V. and Marucheck, A.S. (1997) 'The relationship between EDI and supplier reliability', The Journal of Supply Chain Management, Vol. 33, No. 3, pp.30-35.

Zygmunt, M. (2010) 'Ontologies and agents for better information flow in logistics', International Journal of Logistics Systems and Management, Vol. 6, No. 2, pp.135-148. 